IZA DP No. 4313

A Suggested Method for the Measurement of World-Leading Research (Illustrated with Data on Economics)

Andrew J. Oswald

July 2009 


\title{
A Suggested Method for the Measurement of World-Leading Research (Illustrated with Data on Economics)
}

\author{
Andrew J. Oswald \\ University of Warwick \\ and IZA
}

Discussion Paper No. 4313

July 2009

IZA
P.O. Box 7240
53072 Bonn
Germany

Phone: +49-228-3894-0

Fax: +49-228-3894-180

E-mail: iza@iza.org

\begin{abstract}
Any opinions expressed here are those of the author(s) and not those of IZA. Research published in this series may include views on policy, but the institute itself takes no institutional policy positions.

The Institute for the Study of Labor (IZA) in Bonn is a local and virtual international research center and a place of communication between science, politics and business. IZA is an independent nonprofit organization supported by Deutsche Post Foundation. The center is associated with the University of Bonn and offers a stimulating research environment through its international network, workshops and conferences, data service, project support, research visits and doctoral program. IZA engages in (i) original and internationally competitive research in all fields of labor economics, (ii) development of policy concepts, and (iii) dissemination of research results and concepts to the interested public.
\end{abstract}

IZA Discussion Papers often represent preliminary work and are circulated to encourage discussion. Citation of such a paper should account for its provisional character. A revised version may be available directly from the author. 


\section{ABSTRACT}

\section{A Suggested Method for the Measurement of World- Leading Research (Illustrated with Data on Economics)}

Countries often spend billions on university research. There is growing interest in how to assess whether that money is well spent. Is there an objective way to assess the quality of a nation's world-leading science? I attempt to suggest a method, and illustrate it with modern data on economics. Of 450 genuinely world-leading journal articles, the UK produced 10\%, and the rest of Europe slightly more. Interestingly, more than a quarter of these elite UK articles came from outside the best-known university departments. The proposed methodology could be applied to almost any academic discipline or nation.

JEL Classification: A1, O38

Keywords: science, evaluation, European economics, United Kingdom, peer-review, Research Excellence Framework (REF), citations, Research Assessment Exercise (RAE)

Corresponding author:

Andrew J. Oswald

Department of Economics

University of Warwick

Coventry CV4 7AL

United Kingdom

E-mail: andrew.oswald@warwick.ac.uk

\footnotetext{
*Bruce Charlton of Newcastle University has given me extremely helpful suggestions on this paper. I have also benefited from the comments of the editor Tibor Braun, and of Giuseppe Bertola, Danny Blanchflower, Richard Blundell, Ian Diamond, Jacques Dreze, Amanda Goodall, Steffen Huck, Joao Jalles, Jim Malcomson, Ben Martin, Hashem Pesaran, Neil Shephard, Bill Starbuck, Tony Thirlwall, John Van Reenen, Steve Venti, John Vickers, Bruce Weinberg and Tim Worrall. I have deliberately not discussed this paper, originally entitled 'World-Leading Research and Its Measurement', with the Economics RAE Panel member from Warwick University, Steve Broadberry, and have no way of knowing if the RAE Panel used data like mine. I thank Cornell University and the University of Zurich for visiting professorships in 2008. Thanks go to the ESRC for research support.
} 
A Suggested Method for the Measurement of World-Leading Research (Illustrated with Data on Economics)

\author{
Andrew J Oswald \\ Department of Economics \\ University of Warwick
}

\begin{abstract}
"4* - Quality that is world-leading in terms of originality, significance and rigour...comparable to the best work in the field or sub-field whether conducted in the UK or elsewhere. Such work ... has become, or is likely to become, a primary point of reference in its field or sub-field."

UK Research Assessment Exercise: RAE 2008 www.rae.ac.uk
\end{abstract}

\title{
1. Introduction
}

Countries routinely spend huge sums of money on scientific research in their universities. The issue dealt with in this paper is how in an objective way a national Research Assessment Exercise can assess the world-class research coming from a country. Does somewhere like the United Kingdom -- adjusting for the nation's size -- really compete effectively with the United States ${ }^{1}$, for example, in the production of major new ideas?

The results of the RAE 2008 exercise, which were based on peer-review decisions by panels of (almost entirely) UK academics, suggest that the UK is outstanding at the subject of economics. My discipline was ranked as the United Kingdom's best subject. The major departments had strikingly large proportions of their work assessed as $4^{\star}$, namely, as world-leading. However, journalists and others have asked if this result is believable or is instead a result of grade inflation.

A related, and perhaps particularly important, concern is whether RAE scores truly measure those iconoclastic papers that make a difference or instead simply capture professional soundness ${ }^{2}$.

\footnotetext{
1 Throughout the paper, I will, in the background, try to bear in mind relative population sizes, and in particular that the UK is less than one tenth the size of North America + Continental Europe + Japan.

2 I have been particularly influenced by Bruce Charlton's and Peter Andras's CHARLTON AND ANDRAS [2008] long-held view that we should evaluate whether the UK is producing revolutionary science and not merely normal, solid science. Bruce Charlton has pointed out to me that some nonrevolutionary papers acquire high numbers of citations. He is plainly right. However, high citations numbers are presumably a necessary if not a sufficient condition, and I therefore feel the later exercise is potentially useful.
} 
When the problem is how to judge the quality of a country or a university department, it is likely that self-interest and subconscious biases will play a role. My instinct is that as academics we suffer from -- and here I include myself -- the following biases:

(i) we tend to overestimate the importance of our own department;

(ii) we tend to overestimate the importance of our own sub-field of economics;

(iii) we tend to be badly informed about how influential the articles can be from a range of journals (it has become common, in my 30-year professional lifetime, to hear people focus on a tiny number of journal 'labels' per se, and even sometimes to speak as though a publication in a place like the American Economic Review is an end in itself rather than mattering for its content or its contribution to human welfare);

(iv) we tend to be poorly informed about the latest flow of research and excessively influenced by out-of-date stock variables (such as, for example, the long-standing reputation of another department, or of a particular economist).

This article suggests a methodology that I hope disinterested observers could agree upon ex ante, namely, before they see the data on how they and their own department do. The proposed method is a simple one to implement. By its nature, any findings from it can be checked by others. This seems important.

I collect data on the world's most-cited economics articles over the period of the RAE, namely, from 2001-2008. I then calculate the proportion of articles from the UK. My attempted aim, here, is to make operational the kind of $4^{*}$ concept encapsulated in the quote at the beginning of the paper. [Anticipating what is to come, for a journal such as the American Economic Review, for example, the later suggested method ultimately means that I take the $3 \%$ most-cited AER articles from all countries and then, from within that already 
highly select group, work out the percentage of these influential articles that originated from a university in the United Kingdom.] ${ }^{3}$

I check the numbers also for other European countries. The paper's findings seem relevant to the concerns of MACHIN and OSWALD [2000], NEARY et al [2003], DREZE and ESTEVAN [2006] and CARDOSO et al [2008].

My suggested method can be used in other settings. The exercise might perhaps usefully be done for European research across a range of academic disciplines.

\section{The Method}

I use data from the ISI Web of Science, which is produced by Thomson. It is probably the most widely used source of citations data. Google Scholar and Scopus are possible alternatives. It would be interesting to check the later calculations on such data, although it would be surprising to me if the conclusions changed.

Citations ${ }^{4}$ are taken here as a proxy for the objective quality of an article (measured with the benefit of hindsight). Such an approach is defensible but imperfect. I shall not here rehearse the possible difficulties.

\footnotetext{
3 As one reader put it, this is a highly 'non-linear' method. It puts a large weight on the very best articles in a scholarly discipline. But something of this type is required if we are trying to design a criterion for the upper $4^{\star}$ grade in a system, such as RAE 2008 , where there are three categories of international excellence. It also recognizes the admittedly inegalitarian skewness in intellectual productivity -- a phenomenon sometimes known as Lotka's Law -- whereby a rather small proportion of articles or people produce the majority of the work of lasting impact. I include self-citations because there is a case for leaving them in and they make only a trivial difference in the case of highly-cited papers such as those covered here; I do not weight by the source of the citing journal; doing so would in my judgment be against the spirit of free competition among intellectual ideas. Nevertheless, I remain conscious of the difficulties and sociological influences pointed out by BORNMANN and DANIEL [2008].

4 See work such as HAMERMESH et al [1982], OPPENHEIM [1995], HAMERMESH and SCHMIDT [2003], HAMERMESH and PFANN [2008], and GOODALL [2006, 2009], in which citations are treated as real signals. A particularly early and innovative paper, which remains unpublished, is SMART and WALDFOGEL [1996]. Some defence against possible peer review bias is provided by OSWALD and JALLES [2007]. However, citations are not free of error, and in the long run it may not be sensible to see citations as unambiguously valuable (the more that citations are emphasized, as in this article I would accept, the more that their signalling value will be eroded). HUDSON [2007] identifies some serendipitous influences on citations totals.
} 
The later calculations reveal that this country has produced some of the mostcited articles in the world in a number of important economics field journals. It has also been the source of some of the most influential articles in the AER, Review of Economic Studies, and Econometrica. But it did not do well in certain other journals, especially the Quarterly Journal of Economics and Journal of Political Economy. On balance, I conclude that for its size the UK comes out fairly strongly on objective criteria.

I take the journals listed by the Helpman Committee in the recent ESRC Benchmarking Report on Economics in the United Kingdom, HELPMAN et al [2008]. There is little dispute that these are important journals. There are 22 of them. They are divided into 9 general journals and 13 field journals. The journals are the American Economic Review, Economic Journal, Review of Economic Studies, Econometrica, International Economic Review, Review of Economics and Statistics, Journal of the European Economic Association, Journal of Political Economy, Quarterly Journal of Economics, Journal of Econometrics, Journal of Public Economics, Journal of Development Economics, Journal of Health Economics, Journal of Monetary Economics, Journal of International Economics, Journal of Finance, Rand Journal of Economics, Journal of Urban Economics, Journal of Labor Economics, Journal of Environmental Economics and Management, Journal of Law and Economics, and Journal of Economic Theory.

It would certainly be possible to object that a few significant journals are missing from these (the Journal of Financial Economics and the Journal of Economic History ${ }^{5}$, for example), but I adopt this list because it is the one chosen by Helpman and thus for this particular study helps avoid suggestions that I was consciously or unconsciously biased in my selection.

\footnotetext{
5 I wanted to have an economic history journal, because I think that sub-field is particularly important. But over the period even the Journal of Economic History is comparatively little-cited. The marginal cites on the $10^{\text {th }}$ most-cited paper in JEH is 11 . So I decided, reluctantly, that I could not quite justify including this with the Helpman list. In passing, two high-impact journals, the Journal of Economic Literature and Journal of Economic Perspectives, are also omitted from the Helpman list -- presumably because they are collections of review articles. Two other omitted journals are the newish but increasingly important ones of the Journal of Economic Geography and Games and Economic Behaviour. In an Appendix, for completeness, I present UK results for these kinds of extra journals, but I do not include these data in the text discussion.
} 
For each journal, I searched on articles published between January 2001 and December 2008. Thus I included an extra year of publications after the official end of the RAE period (though this has no material effect on citations numbers). I used the rank-by-citations facility of the Web of Science to order these from the most-cited downwards. I then searched as carefully as possible by hand through the articles for the UK-based ones ${ }^{6}$. The problem with not doing this by hand is that any mechanical search on England will throw up articles that are not truly from England - such as those authored by Americans with an honorary affiliation to the CEPR in London. ${ }^{7}$

It is worth emphasising that there is evidence that early citations numbers to an article are a good indicator of long-run citations numbers. See, for example, ADAMS [2005]. In other words, if an article acquires few citations early on it is unusual -- of course there are occasional exceptions -- for it ever to acquire a high number.

Two caveats on the use of citations -- suggested to me by Bill Starbuck -might be added in passing. First, because Americans outnumber everyone else in terms of the numbers of academics and the amounts of money spent on journals, judgments by Americans dominate the citations data. Insofar as there may be cultural differences between American and British of European researchers, American values then count for a lot. Second, methodological, abstract-theoretical and review articles receive more citations than do empirical articles. This is probably due to the use of review-theory articles as shorthand for "I am familiar with the literature".

The key data are set out in Table 1. It tells us the influential recent articles from UK economics and, in particular, where they lie in a world-ranking of influence.

\footnotetext{
6 This is a tricky thing to do completely accurately (occasionally the addresses of authors can be hard to work out), and it is likely that small errors of counting remain, but it is too be hoped that they are randomly distributed across universities.

7 It is now believed that this error was made by Evidence Ltd in their work for the Helpman Report HELPMAN et al [2008], but the company has not provided me with enough information to judge its size.
} 
To try to adjust for the fact that some journals attract a particularly large quantity of good articles, I allow different journals to have different numbers of articles in the key table -- 50 for the American Economic Review, 10 for the Economic Journal, and so on. These cut-offs were chosen to try to be fair to the different journals. I attempted approximately to equalize the numbers of citations of the marginal excluded article.

To give a sense of how selective the mechanism is, we are choosing in the case of the AER just the top 50 articles out of 1500 published articles over the period, namely, one article in thirty. This is an extraordinarily tough standard to set but it is designed to get at the principle of " $4{ }^{\star} \ldots$ a primary reference in its field".

My method differs from, but I hope is complementary to, the work of VASILAKOS et al [2007].

To read Table 1, the procedure is the following ${ }^{8}$. Take the numbers in the top row as an example. These tell us that if we look at the 50 most-cited articles published by all countries in the American Economic Review over the 20012008 period then the UK was the source of four of these out of the fifty. The UK ones were the $12^{\text {th }}$ most-cited article, the $32^{\text {nd }}, 35^{\text {th }}$, and $38^{\text {th }}$. Moreover, these four articles came, respectively, from Warwick and LSE on the first, LSE on the second, Cambridge on the third, and LSE on the fourth. It can be seen from the table that the UK attained the top slot in the Rand Journal, the International Economic Review, Journal of Econometrics, and Journal of Public Economics; $2^{\text {nd }}$ in the Journal of Health Economics; $3^{\text {rd }}$ in the Journal of Development Economics; and $4^{\text {th }}$ in the Journal of International Economics, the Journal of Monetary Economics, and the Journal of Urban Economics.

\footnotetext{
8 Neil Shephard has suggested to me that ideally the individual papers should be normalized by their year of publication (because a publication in 2001 has had longer to build up cites than one published in 2006). He is right, of course. The reason I do not do so here, and why I use a form of simple averaging, is that I am trying to assess UK economics rather than individual researchers' work.
} 
This is a substantial achievement for the United Kingdom. Nevertheless, although I do not report the full data, the UK numbers are far behind those for the (obviously much larger) United States.

These citations totals were collected in December of 2008. They will, of course, increase through time.

Two UK articles seem to deserve special mention. They are IM et al in the 2003 Journal of Econometrics and BRAZIER et al in the Journal of Health Economics in 2002. Remarkably, both have already acquired over 300 cites (when measured in December 2008). The first of these is from Cambridge+Edinburgh and the second is from Sheffield. I take off my hat -as we say in England -- to these authors.

\section{Institutions' Contributions to the UK World-Leading Papers}

It seems of interest to look at which institutions contributed these 45 important articles 9 :

$\underline{\text { Web of Science Data }}$

LSE $\quad 11$ articles

Oxford 11

Warwick 6

Cambridge 4

UCL $\quad 4$

Edinburgh 2

LBS 2

Nottingham 2

Strathclyde 2

9 Hashem Pesaran has made the point to me that ideally we need to know where the important research was done -- rather than simply where the author is when credited in the journal. I would like to be able to do this. But it is not possible, at least for me, to adjust the data in this way. 
and, interestingly, and somewhat to my surprise, 12 other universities or centres contributed one (or to one) article each. These universities are: York, Essex, Cardiff, QMW, Kent, St Andrews, Lancaster, the Institute for Fiscal Studies, Sheffield, Leicester, Royal Holloway, and UEA. In other words, research excellence, even on this rare and rarified criterion, of having had major influence on the profession, is found widely across the country. It should be noted that my measure here assigns full weight to a jointly authored article, so that a tri-authored Article $Y$ by economists from Universities $A, B, C$ would see each of those universities credited above.

\section{Two Further Checks}

\section{A Repec test}

It was suggested to me that another data source for doing this kind of calculation $^{10}$ is IDEAS through www.Repec.org. This counts the number of cites in working papers and not just in published journals.

Hence I did the following. On the Repec site, there is a list of papers called Top Recent Research Items by Number of Citations. A recent research paper is defined as "a research item whose last version was published less than five years ago, and whose first version was published less than ten years before the last version."

This is a particularly highly selected group of papers. Only the top 82 economics papers in the world are listed. [It is worth noting that the list constantly changes on the Repec site as the data are updated.]

In so far as can be judged from this necessarily small sample, do we see broadly the same patterns as in ISI Web of Science data? It turns out that we do.

10 Thanks go to Richard Blundell for this suggestion. 
Of the 82 papers, ranked by their number of citations in the IDEAS Repec database, the UK-source items are in the following positions in the world ranking:

$\underline{\text { Repec Data }}$

$2^{\text {nd }}$ most-cited recent paper in the world (Cambridge+Edinburgh)

$13^{\text {th }}$ (Warwick)

$19^{\text {th }}(L B S)$

$33^{\text {rd }}$ (Oxford)

$44^{\text {th }}(U C L)$

$69^{\text {th }}(L S E)$

$73^{\text {rd }}$ (Warwick)

$75^{\text {th }}($ Oxford $)$

and, overall, this is again consistent with a rough rule of thumb of $10 \%$ of influential papers coming from the UK. Of the 82 in the world, 8 were wholly or partly from universities in the United Kingdom.

The potentially special case of Econometrica

It was suggested to me that the journal Econometrica is unusual, among all economics journals, because it produces important papers that are technical and have a relatively slow build-up in, but eventually an unusually long-lived number of, citations. I looked at this in the historical data and there seems some mild evidence for it when Econometrica is compared to journals like the Economic Journal but not in any clear way with respect to journals like the American Economic Review. Although I therefore think the case for treating Econometrica differently is relatively weak, as one additional experiment I extended the number of papers treated to 100 in the case of Econometrica (rather than to 50 as in the table). This means allowing Econometrica articles to be included all the way down to a -- lenient -- marginal cut-off number of cites of 20. 
If Econometrica is allowed this latitude, little happens to the conclusions of the paper. The $10 \%$-UK-articles rule of thumb is only slightly affected. The ranking of UK departments remains the same, although UCL, Cambridge and the University of York come up fractionally, because they obtain extra articles. LSE continues to top the table (and has three extra articles). A number of other departments get one more. But, overall, there is not much change in the substantive results.

\section{Can We Compare Against Other Disciplines?}

This paper proposes a methodology that could be applied in most other disciplines. Someone who -- unlike me -- can identify the top 20 journals in mathematics, or anthropology, or chemistry, and can use the ISI Web of Science to do a citation count, can do this same exercise for those other scholarly disciplines. In my judgment, that comparison would be interesting, and would allow a sharp test of which parts of UK research are truly highlyranked in the world.

The closest I can come to the spirit of this across disciplines is the following calculation. New work by Bruce Weinberg, WEINBERG [2009], ranks the quality of disciplines in the UK in an interesting way. Weinberg uses the Highly Cited Researcher database produced by ISI, available at www.isihighlycited.com. He shows that of the world's most highly cited economists $^{11}$ approximately $4 \%$ come from the UK. The Highly Cited Researcher database covers data from 1970 to today, so in a sense is an outof-date snapshot of the health of UK academia. Weinberg's interesting Table 3 shows that the best UK subjects, when judged by the largest \% of worldranked researchers, are Pharmacology (18\% of the world's most-cited researchers), Plant and Animal Science (13\%), Neuroscience (12\%), and Clinical Medicine (11\%). No other subject gets above $9 \%$.

11 In fact the ISI database classifies Economics+Business together, and it appears from the Highly Cited Researcher data that the lack of top business researchers in the UK is what really pulls down our average to the $4 \%$. On its own, my calculations suggest that (purely) UK economics would rank at about $7 \%$. 
If (i) we assume that the current quality of economics is represented by my earlier number of $10 \%$ of the world's highly cited articles, and (ii) assume that in the long run there is a one-to-one relation between the proportion of highly cited articles and the proportion of highly cited researchers, then we might conjecture that UK economics has improved and is now closer to a steadysteady in which this country will have $10 \%$ of the world's top researchers. If so, and it is certainly possible to think of objections to my two assumptions, then Economics could be seen as one of the best and most highly ranked subjects in the United Kingdom. Unless these four subjects have all declined in quality, however, Economics would still not be the top discipline in the country, even if everything else remained the same. ${ }^{12}$

\section{Other European Countries}

Table 2, as an extension suggested to me by Jacques Dreze, re-does the exercise for the rest of the European nations. I have compressed the data into one table, but the identities of the countries can be read from Table 2.

It can be seen that the non-UK part of Europe contributes 56 out of the whole set of 450 world-leading papers ${ }^{13}$. This is slightly more than the UK total.

\section{On Open-mindedness}

In doing this analysis, I have discovered that some people are powerfully influenced by their prior beliefs. They tend to extrapolate from how a university department is doing in their particular sub-field to how (they imagine) that department must be doing on average across all sub-fields. They are, unsurprisingly, attracted to assessment schemes that favour their own universities and their particular interests.

\footnotetext{
12 Bruce Charlton's early intuition in discussions with me was, interestingly, that medicine and allied subjects are the UK's top disciplines.

13 Here the performance on top-ranked AER papers seems particularly creditable, although, as with some of the UK work, it should perhaps also be recorded that these few papers were quite heavily coauthored with Americans.
} 
As an example, early on in this work I explained my proposed method to an experienced American applied economist (whose name I have suppressed from my acknowledgments). After some minutes, he nodded, and said "Yes Andrew, this method makes good sense. It is a natural way to do the calculation in a scientifically objective way". He then wanted to know the results. After a minute or two of looking at them, he said "oh no, I now think there must be a problem with the method, because University $X$ should be higher in this league table". What I learned from him and others is that even experienced empirical researchers will agree to a method in advance and yet -- against the spirit of science -- want to change their mind unless the data come out in accord with their original views. This is very human but makes it hard to get people to listen to actual data. My conjecture is that he thought University $X$ should do better because that department is strong in the kind of work my American friend himself does; but it is not possible to say for sure.

Some economists will look at this paper's data and prefer to stick to their prior intuitions about their country, department and university. But, bearing in mind the four biases discussed at the start of the paper, I hope most will be attracted to the idea that assessments should be made, at least in part, by using objective evidence of this kind.

\section{Conclusions}

This article proposes a way to capture the concept of 'world-leading' work. It examines objective data, for the UK's Research Assessment Exercise period of 2001-2008, on the world's most influential economics articles. The proposed approach -- a bibliometric one ${ }^{14}$-- can be applied to almost any academic discipline. In principle, its method might be exploited in the next Research Excellence Framework (REF) in the United Kingdom, or in research evaluation exercises in other nations.

\footnotetext{
14 In passing, my own instinct is that a research assessment exercise such as the next so-called Research Excellence Framework (REF) in the United Kingdom should not rely in a mechanical way upon bibliometrics. It should have some element of peer review (or at least peer overview).
} 
Following the Helpman report for the ESRC, I concentrate on 22 well-known economics journals. This is not because I view these as the only journals that matter. But it reduces possible objections that I chose the journals to obtain some desired result.

On balance, I conclude that in economics the United Kingdom comes out moderately well on this criterion. It produces $10 \%$ of the really important work. However, the UK remains far behind the USA. The remainder of Europe -- combined -- produces slightly more than the United Kingdom.

Among a set of 450 genuinely world-leading articles -- these are the mostcited papers produced in the world over the period -- I find that the UK has been the source of 45 of them. In particular, the UK has been the home of the single most-cited article in the Journal of Econometrics, the International Economic Review, the Journal of Public Economics, and the Rand Journal of Economics, and of the second most-cited article in the Journal of Health Economics. A UK departmental ranking on this objective criterion looks somewhat similar to that generated by RAE 2008 data.

A further check using instead Repec data leads to results consistent with the main conclusions. Allowing special treatment for Econometrica (although the case for doing so is unclear to me from the data) also leaves the key results unaffected.

As an additional exercise, the rest of Europe is studied in Table 2. The total number of influential articles from these countries is 56 .

As Table 1 reveals, one quarter of these objectively important UK articles emanate wholly or partly from departments of economics not normally considered to be in the top half-dozen in the country. I had not anticipated this result. It suggests that outstanding work -- a set of genuinely worldleading articles -- comes from a wide range of sources (literally speaking, 21 different universities in Table 1) and by implication that it might be a mistake 
to concentrate funding narrowly 15 on a tiny number of universities. Perhaps economists should take a lead in arguing against a growing modern concern with 'top' departments ${ }^{16}$, 'top' journals, and other monopoly-creating devices.

15 An economist would argue that it is the marginal productivity of research funding that matters. Public discussion, by contrast, is typically about average productivities.

16 See also FREY [2003], STARBUCK [2005], ELLISON [2007], MACDONALD and KAM [2007], OSWALD [2007], and WU [2007]. I would argue, although may be biased, that this paper's bibliometric approach is a way of coping with the serious problem -- pointed out in different ways by STARBUCK [2005] and OSWALD [2007] -- for national scientific evaluation that the elite journals publish many 'poor' articles, that is, ones that go on to have no impact. The paper does this by concentrating on withinjournal rankings of influential articles. 


\section{$\underline{\text { References }}$}

ADAMS, JONATHAN. (2005), Early citation counts correlate with accumulated impact. Scientometrics, 63 (3): 567-581.

BORNMANN, LUTI, AND DANIEL, HANS-DIETER. (2008), What do citation counts measure? A review of studies on citing behavior. Journal of Documentation, 64(1): 45-80.

BRAZIER, JOHN, ROBERTS, JENNIFER, AND DEVERILL, MARK. (2002), The estimation of a preference-based measure of health from the SF-36. Journal of Health Economics, 21 (2): 271-292.

CARDOSO, ANA RUTE, GUIMARAES, PAULO, AND ZIMMERMAN, KLAUS F. (2008), Comparing the early research performance of $\mathrm{PhD}$ graduates in labor economics in Europe and the USA. IZA Discussion Paper, \#3898.

CHARLTON, BRUCE, AND ANDRAS, PETER. (2008), Down-shifting among top UK scientists? The decline of revolutionary science and the rise of normal science. Medical Hypotheses, 70 (3): 465-472.

DREZE, JACQUES H. AND ESTEVAN, FERNANDA. (2006), Research and higher education in economics: Can we deliver the Lisbon objectives? Journal of the European Economic Association, 5 (2): 271-304.

ELLISON, GLENN. (2007), Is peer review in decline? Working paper, MIT. July.

FREY, BRUNO S. (2003), Publishing as prostitution? Choosing between one's own ideas and academic success. Public Choice, 116: 205-223.

GOODALL, AMANDA H. (2006), Should research universities be led by top researchers, and are they? A citations analysis. Journal of Documentation, 62 (3): 388-411.

GOODALL, AMANDA H. (2009), Socrates in the boardroom: Why research universities should be led by top scholars. Princeton University Press. Forthcoming.

HAMERMESH, DANIEL S., JOHNSON, GEORGE E. AND WEISBROD, BURTON A. (1982), Scholarship, citations and salaries: Economic rewards in economics. Southern Economic Journal, 49(2): 472-481.

HAMERMESH, DANIEL S. AND SCHMIDT, PETER. (2003), The determinants of Econometric Society fellows elections. Econometrica, 71, 399-407.

HAMERMESH, DANIEL S. AND PFANN, GERARD. (2008) Markets for reputation: Evidence on quantity and quality in academe. Working paper, University of Texas.

HELPMAN, ELHANAN et al. (2008) ESRC International benchmarking study of UK economics. ESRC. Swindon.

HUDSON, JOHN. (2007), Be known by the company you keep: Citations - quality or chance? Scientometrics, 71(2): 231-238.

IM, KYUNG SO, PESARAN, M. HASHEM AND SHIN, YONGCHEO. (2003), Testing for unit roots in heterogeneous panels. Journal of Econometrics, 115(1): 53-74. 
MACDONALD, STUART AND KAM, JACQUELINE. (2007), Ring a ring o' roses: Quality journals and gamesmanship in management studies. Journal of Management Studies, 44: 640-655.

MACHIN, STEPHEN AND OSWALD, ANDREW J. (2000), UK economics and the future supply of academic economists. Economic Journal, 110: F334-F349.

NEARY, J. PETER, MIRRLEES, JAMES A. AND TIROLE, JEAN. (2003), Evaluating economics research in Europe: An introduction. Journal of the European Economic Assocation. 2003, 1: 1239-1249.

OPPENHEIM, CHARLES. (1995), The correlation between citation counts and the 1992 Research Assessment Exercise Ratings for British library and information science university departments. Journal of Documentation, 51: 18-27.

OSWALD, ANDREW J. (2007), An examination of the reliability of prestigious scholarly journals: Evidence and implications for decision-makers. Economica, 74: 21-31.

OSWALD, ANDREW J. AND JALLES, JOAO. (2007), Unbiased peer review and the averaging fallacy. Working paper, Warwick University.

SMART, SCOTT AND WALDFOGEL, JOEL. (1996), A citation-based test for discrimination at economics and finance journals. Working paper, Indiana University, and NBER paper 5460. January.

STARBUCK, WILLIAM H. (2005), How much better are the most prestigious journals? The statistics of academic publication. Organization Science, 16: 180-200.

VASILAKOS, NICHOLAS, LANOT, GAUTHIER, AND WORRAL, TIM. (2007), Evaluating the performance of UK research in economics. Report sponsored by the Royal Economic Society.

WEINBERG, BRUCE. (2009), An assessment of British science over the $20^{\text {th }}$ century. Economic Journal, forthcoming.

WU, STEPHEN. (2007), Recent publishing trends at the AER, JPE, and QJE. Applied Economics Letters, 14(1): 59-63. 


\section{TABLE 1}

\section{How Did UK Economics Do Over the Period 2001-8 if J udged Against the Most-Cited Articles Produced Around the World?}

Notes to reading this table: the top row means that if we look at the 50 most-cited articles published by all countries in the American Economic Review over the 01-08 period then the UK was the source of the $12^{\text {th }}$ most-cited, and of those ranked $32^{\text {nd }}$, the $35^{\text {th }}$, and the $38^{\text {th }}$. Moreover, these four articles came, respectively, from Warwick and LSE on the first, LSE on the second, Cambridge on the third, and LSE on the fourth.

Different journals are assigned different values of $X$, because some journals here are intrinsically more cited than others. The lower cut-off levels of cites are reported in square brackets in the first column. Hence the number 55 after AER means that the $50^{\text {th }}$ most-cited paper in the American Economic Review attained 55 cites. The Journal of the European Economic Association has only recently started publishing papers so cannot be compared to others on cites.

The citations totals were collected in December of 2008.

\begin{tabular}{|c|c|c|c|c|}
\hline $\begin{array}{c}\text { Journal } \\
\text { [ lower cut-off } \\
\text { marginal \# cites] }\end{array}$ & $\begin{array}{c}\text { Criterion: } \\
\text { Appearing } \\
\text { among the } X \\
\text { most-cited } \\
\text { articles in that } \\
\text { journal where } \\
X \text { here is the } \\
\text { top: }\end{array}$ & $\begin{array}{l}\text { Were } \\
\text { there any } \\
\text { UK papers } \\
\text { within } \\
\text { these top } \\
X \text { articles? }\end{array}$ & $\begin{array}{l}\text { Their } \\
\text { positions } \\
\text { in the } \\
\text { world } \\
\text { rank of } \\
\text { these } \\
\text { most- } \\
\text { cited } X\end{array}$ & $\begin{array}{l}\text { Which UK institutions } \\
\text { were the source of these } \\
\text { highly-ranked papers? }\end{array}$ \\
\hline AER [55] & 50 & Yes & $\begin{array}{c}\text { 12th; } \\
\text { 32nd; } \\
\text { 35th; 38th }\end{array}$ & $\begin{array}{l}\text { Warwick+LSE; LSE; } \\
\text { Cambridge; LSE }\end{array}$ \\
\hline EJ [41] & 10 & Yes & $5 ; 10$ & LSE+Oxford; Nottingham \\
\hline REStud [35] & 20 & Yes & $\begin{array}{c}9 ; 11 ; 12 ; \\
13\end{array}$ & $\begin{array}{l}\text { UCL+Oxford+Cambridge; } \\
\text { LBS; LSE; Cambridge }\end{array}$ \\
\hline Econometrica [32] & 50 & Yes & $\begin{array}{c}11 ; 17 ; 19 ; \\
29 ; 36\end{array}$ & $\begin{array}{c}\text { Oxford; York; UCL; Warwick; } \\
\text { Oxford }\end{array}$ \\
\hline IER [29] & 10 & Yes & 1 & Warwick+Cardiff+Oxford \\
\hline REStats [39] & 20 & Yes & 13 & Warwick \\
\hline JEEA [8] & 10 & No & & \\
\hline JPE [30] & 50 & Yes & 45 & Essex \\
\hline QJE [45] & 50 & Yes & 40 & $\mathrm{UCL}$ \\
\hline JEconometrics [39] & 20 & Yes & $\begin{array}{l}1 ; 6 ; 10 ; \\
14 ; 15 ; 19\end{array}$ & $\begin{array}{c}\text { Cambridge+Edinburgh; } \\
\text { Edinburgh+QMW; } \\
\text { Kent+StAndrews; } \\
\text { Lancaster+Strathclyde; IFS; } \\
\text { Oxford } \\
\end{array}$ \\
\hline JPubEcon [35] & 10 & Yes & $1 ; 5$ & Warwick; LSE \\
\hline JDevEcon [30] & 10 & Yes & $3 ; 7$ & Nottingham; Oxford \\
\hline JHealthEcon [36] & 10 & Yes & $2 ; 9$ & Sheffield; Leicester \\
\hline JMonetaryEcon [51] & 10 & Yes & $4 ; 7$ & Royal Holloway; Oxford \\
\hline JIntEcon [27] & 10 & Yes & $4 ; 5 ; 10$ & Warwick; LSE; LBS \\
\hline JFinance [51] & 50 & Yes & 41 & Oxford \\
\hline Rand Journal [44] & 10 & Yes & $1 ; 6 ; 10$ & Oxford; LSE; Oxford \\
\hline JUrbanEcon [22] & 10 & Yes & $4 ; 7 ; 10$ & UCL+LSE; LSE; LSE \\
\hline JOLE $[28]$ & 10 & No & & \\
\hline JEnvEcon\&Man[36] & 10 & Yes & $3 ; 7$ & Strathclyde; UEA \\
\hline JLaw\&Econ [22] & 10 & No & & \\
\hline JET [34] & 10 & No & & \\
\hline $\begin{array}{l}\text { Total \# world-leading } \\
\text { papers from the UK }\end{array}$ & & & 45 & \\
\hline
\end{tabular}


TABLE 2

\section{How Did the Rest of European Economics Do Over the Period 2001-8 if Judged Against the Most-Cited Articles Produced Around the World?}

Notes to reading this table: As before.

\begin{tabular}{|c|c|c|c|c|}
\hline $\begin{array}{c}\text { Journal } \\
\text { [lower cut-off } \\
\text { marginal \# cites] }\end{array}$ & $\begin{array}{c}\text { Criterion: } \\
\text { Appearing } \\
\text { among the } X \\
\text { most-cited } \\
\text { articles in that } \\
\text { journal where } \\
X \text { here is the } \\
\text { top: }\end{array}$ & $\begin{array}{l}\text { Were there } \\
\text { any (non- } \\
\text { UK) } \\
\text { European } \\
\text { papers } \\
\text { within these } \\
\text { top X } \\
\text { articles? }\end{array}$ & $\begin{array}{l}\text { Their } \\
\text { positions } \\
\text { in the } \\
\text { world } \\
\text { rank of } \\
\text { these } \\
\text { most- } \\
\text { cited X }\end{array}$ & $\begin{array}{l}\text { Which countries were } \\
\text { the source of these } \\
\text { highly-ranked papers? }\end{array}$ \\
\hline AER [55] & 50 & Yes & $\begin{array}{l}2^{\text {nd }} ; 3^{\text {rd }} ; 5^{\text {th }} ; \\
33^{\text {rd }} ; 34^{\text {th }} ; \\
35^{\text {th }} ; 47 \text { th }\end{array}$ & $\begin{array}{c}\text { Switzerland; Germany; } \\
\text { Germany; France; Spain; } \\
\text { Italy; Spain }\end{array}$ \\
\hline EJ [41] & 10 & Yes & 4 & Netherlands \\
\hline REStud [35] & 20 & Yes & $5 ; 15 ; 19$ & France; Spain; France \\
\hline Econometrica [32] & 50 & Yes & $\begin{array}{l}17 ; 18 ; 19 ; \\
21 ; 26 ; 27 ; \\
32 ; 34 ; 43\end{array}$ & $\begin{array}{c}\text { France; Spain; } \\
\text { France+Germany; } \\
\text { Denmark; France; } \\
\text { Germany; Netherlands; } \\
\text { Denmark; France }\end{array}$ \\
\hline IER [29] & 10 & Yes & 2 & Italy+Belgium \\
\hline REStats [39] & 20 & No & & \\
\hline JEEA [8] & 10 & Yes & $\begin{array}{c}1 ; 2 ; 7 ; 9 ; \\
10\end{array}$ & $\begin{array}{l}\text { Spain; Sweden; } \\
\text { Sweden+I reland; Spain; } \\
\text { Italy+Switzerland }\end{array}$ \\
\hline JPE [30] & 50 & Yes & $10 ; 24$ & $\begin{array}{c}\text { Sweden+Belgium+Italy; } \\
\text { I taly }\end{array}$ \\
\hline QJE [45] & 50 & Yes & $\begin{array}{l}21 ; 26 ; 40 ; \\
50\end{array}$ & France; Italy; France; Italy \\
\hline JEconometrics [39] & 20 & Yes & $4 ; 20$ & $\begin{array}{c}\text { Netherlands; } \\
\text { France+Belgium }\end{array}$ \\
\hline JPubEcon [35] & 10 & Yes & $2 ; 10$ & $\begin{array}{c}\text { Italy; } \\
\text { Switzerland+Denmark }\end{array}$ \\
\hline JDevEcon [30] & 10 & Yes & $1 ; 2 ; 3$ & Denmark; Norway; France \\
\hline JHealthEcon [36] & 10 & Yes & $8 ; 10$ & Sweden; Germany \\
\hline JMonetaryEcon [51] & 10 & No & & \\
\hline JIntEcon [27] & 10 & Yes & $1 ; 4 ; 7 ; 9$ & $\begin{array}{c}\text { Ireland; Germany; } \\
\text { Italy+Spain+Germany; } \\
\text { Spain }\end{array}$ \\
\hline JFinance [51] & 50 & Yes & $\begin{array}{l}3 ; 10 ; 19 ; \\
25 ; 41\end{array}$ & $\begin{array}{l}\text { Netherlands; France; } \\
\text { Spain; Finland; Finland }\end{array}$ \\
\hline Rand Journal [44] & 10 & Yes & 9 & France \\
\hline JUrbanEcon [22] & 10 & No & & \\
\hline JOLE [28] & 10 & Yes & 4 & France \\
\hline JEnvEcon\&Man[36] & 10 & No & & \\
\hline JLaw\&Econ [22] & 10 & Yes & 2 & Austria \\
\hline JET [34] & 10 & Yes & $3 ; 5 ; 6$ & Italy; France; Spain \\
\hline $\begin{array}{c}\text { Total \# world-leading } \\
\text { papers from rest of } \\
\text { Europe }\end{array}$ & & & 56 & \\
\hline
\end{tabular}




\section{APPENDIX}

\section{Further J ournals and UK Articles}

Notes to reading this table: As before, except that the data were collected in January 2009.

\begin{tabular}{|c|c|c|c|c|}
\hline $\begin{array}{c}\text { Journal } \\
\text { [lower cut-off } \\
\text { marginal \# } \\
\text { cites] }\end{array}$ & $\begin{array}{c}\text { Criterion: } \\
\text { Appearing } \\
\text { among the } X \\
\text { most-cited } \\
\text { articles in that } \\
\text { journal where } X \\
\text { here is the top: }\end{array}$ & $\begin{array}{l}\text { Were there } \\
\text { any UK } \\
\text { papers } \\
\text { within } \\
\text { these top X } \\
\text { articles? }\end{array}$ & $\begin{array}{l}\text { Their } \\
\text { positions } \\
\text { in the } \\
\text { world } \\
\text { rank of } \\
\text { these } \\
\text { most- } \\
\text { cited X }\end{array}$ & $\begin{array}{c}\text { Which UK institutions } \\
\text { were the source of } \\
\text { these highly-ranked } \\
\text { papers? }\end{array}$ \\
\hline Economica [15] & 10 & Yes & $\begin{array}{l}1^{\text {st }} ; 3^{\text {rd }} ; 5^{\text {th }} \\
6^{\text {th; }} ; 7^{\text {th; }} ; 8^{\text {th }} ; \\
9 \text { th }\end{array}$ & $\begin{array}{l}\text { Brunel+Kent; Essex; LSE; } \\
\text { Warwick; Cambridge+UCL; } \\
\text { Leicester; Cardiff+Aberdeen }\end{array}$ \\
\hline $\begin{array}{l}\text { European } \\
\text { Economic } \\
\text { Review [44] }\end{array}$ & 10 & Yes & $8 ; 10$ & UCL; Warwick \\
\hline $\begin{array}{c}\text { Ecological } \\
\text { Economics }[46]\end{array}$ & 10 & Yes & $3 ; 7$ & UEA; UEA \\
\hline $\begin{array}{c}\text { Games \& } \\
\text { Economic } \\
\text { Behavior [32] }\end{array}$ & 10 & Yes & 10 & Royal Holloway \\
\hline $\begin{array}{l}\text { Journal of } \\
\text { Economic } \\
\text { History [10] }\end{array}$ & 10 & No & & \\
\hline $\begin{array}{c}\text { Journal of } \\
\text { Economic } \\
\text { Geography [35] }\end{array}$ & 10 & Yes & $1 ; 3 ; 4 ;$ & $\begin{array}{c}\text { Cambridge+Edinburgh; } \\
\text { LSE; Cardiff }\end{array}$ \\
\hline $\begin{array}{c}\text { Journal of } \\
\text { Financial } \\
\text { Economics [36] }\end{array}$ & 50 & Yes & $44 ; 50$ & $\begin{array}{l}\text { Deutsche Bank, London; } \\
\text { LBS }\end{array}$ \\
\hline $\begin{array}{c}\text { Journal of } \\
\text { Economic } \\
\text { Behavior and } \\
\text { Organization } \\
{[23]}\end{array}$ & 10 & Yes & 8 & UCL+Royal Holloway \\
\hline $\begin{array}{c}\text { Oxford } \\
\text { Economic } \\
\text { Papers [16] } \\
\end{array}$ & 10 & Yes & $\begin{array}{c}2 ; 5 ; 6 ; 7 ; \\
8 ;\end{array}$ & $\begin{array}{c}\text { Oxford; UCL; Oxford; York; } \\
\text { Oxford }\end{array}$ \\
\hline $\begin{array}{l}\text { Scandinavian } \\
\text { Journal of } \\
\text { Economics }[16]\end{array}$ & 10 & Yes & $4 ; 6$ & UCL+LSE; QMW \\
\hline $\begin{array}{l}\text { Economics } \\
\text { Letters [20] }\end{array}$ & 10 & No & & \\
\hline
\end{tabular}

